\title{
Do Corporate Governance Indicators Lead the Firm to Adopt High/Low Level of Financial Leverage? Case of Jordan
}

\author{
Ahmad Alqisie \\ College of Business and Finance, the World Islamic Sciences \& Education University \\ P.O. box 1101 - Amman, 11947 Jordan \\ Tel: 962- 79- 671-1360_E-mail: Ahmadalqisie@yahoo.com \\ Received: May 13, 2014 \\ doi:10.5296/jmr.v6i3.5622 \\ Accepted: June 24, 2014 \\ Published: July 1, 2014 \\ URL: http://dx.doi.org/10.5296/jmr.v6i3.5622
}

\begin{abstract}
This study aimed to provide evidence of whether or not the corporate governance indicators (CGI) of the Jordanian industrial firms listed at Amman Stock Exchange (ASE) lead the firm to adopt high/low level of financial leverage and to determining which of them have significant effect. The study population consists of (96) Jordanian industrial firms' governance of the Jordanian firms listed at (ASE). (48) Firms were selected randomly to be used in the study. The study found that, corporate governance indicators do matter in Jordanian industrial firms; ownership concentration and Board size have significant negative relationship with financial leverage, when they increases financial leverage decreases, which means they lead the firm to adopt low level of external debt, while CEO duality and CEO compensation have insignificant positive relationship with financial leverage.
\end{abstract}

Keywords: Corporate governance indicators, Financial leverage, Industrials firms, Jordan 


\section{Introduction}

Corporate Governance is considered as one of the important topics that appeared in the financial markets during recent years, where many of the scholars and researchers from various fields and specialties studied from several different aspects, all interpreted from his perspective. The issue of corporate governance can affect all aspects of the company and management, both in terms of performance management, earnings management and its financial structure (Awan \& Khan, 2012). The practice of good corporate governance has become an important requirement to run the company efficiently on a global level, the term corporate governance is relatively new as it is used on the general level and academic level; interest in them has increased dramatically over the past two decades. Shleifer and Vishny defined it as follow: "it deals with the ways in which to ensure providers of money for the company to get a return on their investment". The Corporate Governance indicators reassure investors in the companies that they would receive an adequate return on their investment, but if these indicators are exist or do not function properly, external investors will not lend the company and will not buy their securities (Shleifer \& Vishny, 1997). As thus, the consequent resort company to rely on internal sources, which consisting of internal cash flows and the money collected to fund current operations and profitable investment opportunities. So, if the Company is unable to finance these opportunities from its internal sources, they will lose it, and this leads to weaken its financial performance, which will affect the market value of the company and therefore the shareholders' wealth.

Accordingly, the management of the company's capital structure, which reflects the concept of financial leverage and the manner in which they are managed by managers, is considered as one of the most important topics in this context. Therefore, this study is interested in identifying factors that affect the company's trends toward adopt high or low level of debt (financial leverage) in its capital structure to finance its operations through a set of corporate governance indicators within one emerging capital markets (Amman Stock Exchange)

\section{Problem of the study}

Practicing good corporate governance plays an important role in helping companies to achieve their goals; maximizing the value of the company and optimizing shareholders wealth, through reassure investors that, they will get adequate returns on their investments. As a result of multiple indicators of corporate governance in terms of the Board size, equity structure, leadership duality, CEO compensation and the different preferences towards funding investments in the company by external or internal resources, this study aimed to examine whether or not the corporate governance indicators (independent variables) are taken into consideration at this study lead the Jordanian industrial firms listed on (ASE) to adopt high or low level of financial leverage (Dependent variable), those independent variables are (Ownership Concentration, Board Size, CEO Duality, CEO Compensation). This problem will be answered through the following main question:

Do corporate governance indicators lead the firm to adopt high or low level of financial leverage in Jordanian industrial firms listed in Amman Stock Exchange (ASE)?

\section{Sub-questions:}




\section{Ml Macrothink}

- Does high level of ownership concentration lead the firm to adopt high or low level of financial leverage?

- Does the large size of the Board lead the firm to adopt high or low level of financial leverage?

- Does CEO duality lead the firm to adopt high or low level of financial leverage?

- Do high CEO compensations lead the firm to adopt high or low level of financial leverage?

\section{Significance of the Study}

The importance of the study stems from the following points:

- $\quad$ To provide evidence if the corporate governance indicators as a whole lead the firm to adopt high or low level of financial leverage in industrial firms listed at ASE.

- To specify which of the corporate governance indicators lead the firm to adopt high or low level of financial leverage?

- To provide investors and shareholders with the results of this study to take into consideration when they take their investment decision through recognizing the financial risks.

\section{Literature review}

\subsection{Corporate Governance}

Corporate governance plays a major role in macroeconomic stability; provide the appropriate environment for economic growth as well as society welfare, therefore international institutions give major attention and concerns to this issue at the level of macro and micro aspects, because of the importance of corporate governance at both the country and the corporate levels. Corporate Governance is "a set of relationships between a company's management, its board, its shareholders, and other stakeholders. Corporate governance also provides the structure through which the objectives of the company are set, and the means of attaining those objectives and monitoring performance are determined. Good corporate governance should provide proper incentives for the board and management to pursue objectives that are in the interests of the company and shareholders, and should facilitate effective monitoring; thereby encouraging firms to use resources more efficiently". (OECD, Principles of Corporate Governance, 1999).

Corporate governance refers to the processes and bodies that are responsible for the decision that, in long term, have most influence on the composition of management team, on capital structure, and on taking of important risks for the owners of the company. Mechanisms that protect the interests of the shareholders are known as corporate governance indicators, and firms will face more agency problems (conflict of interest arising between creditors, shareholders and management because of differing goals), and managers of those firm's get more private benefits, if they have weak governance structures (Core, Holthausen, \& Larcker, 1999).

The concept of the principles of corporate governance is the foundation upon which all investors and lenders confidence in the company, the proper practicing of corporate governance can have a significant influence in the strategic decisions of the company, 
including, for example, external funding (debt), which takes on the level of the Board of Directors, so ownership concentration, the Board size, CEO duality (CEO and Chairman of the Board at the same time) and compensations of CEO can have a direct impact on the decisions of the capital structure (Fosberg, 2004, Anderson et al., 2004).

Proportion of ownership concentration in this study is one of corporate governance indicators. It has been noticed that ownership of shares in Jordanian firms listed at (ASE) usually concentrated in a hands of a group of investors who represent financial institutions, insurance companies and government agencies. Many studies have indicated that block shareholders usually prefer internal financing to external financing, because they believes that companies with high leverage will face financial problems in the future. In addition, good control by block shareholders have an impact in increasing the generation of cash inflows, these flows can lower the trend toward adopting external borrowing, and this leads to an inverse relationship between ownership concentration and the level of external finance (Tong and Ning, 2004, Helen et al., 2002, Rehman et al., 2010)). In contrary (Ahmadpour et al., 2012, Driffield et al., 2007) founds a direct positive correlation between ownership concentration and financial leverage.

The Board of Directors constitute the bulk of the company which is responsible for managing the company and its operations, and practiced a vital role in its strategy, especially mixed financing (Gillan, 2006). (Berger, 1997, Abor, 2007, Hasan \& Butt, 2009) founds that companies with large Board put pressure on managers to follow a low level of financial leverage to improve the company's performance, which means a negative relationship between Board size and leverage ratios. While (Wen et al., 2002, Ahmadpour et al., 2012, Ganiyu and Abiodun 2012) founds a positive direct correlation between the Board size and financial leverage, where pointed out that Board with a large volume follows the policy of the high level of leverage to improve the value of the company.

CEO duality is one of corporate governance indicators, which represent the duplication between the position of Chairman of the Board and Chief Executive Officer, this indicates that management of the company is taken by one person, and this situation has a direct impact on funding decisions at the company (Chaghadari, 2011). In companies with CEO duality approach, the crucial question is "who monitors management? Or "who will watch the watchers?" This situation provides CEOs with the opportunity to have a dominant influence on the board's decisions (Zubaidah et al., 2009). The basic principle is that decisions of management in the company are separated from the control decisions, where the decisions of the administration are interested in the implementation of the proposals on the distribution of the company's resources, while control decisions concerned in the control and the adoption of those decisions, therefore it is necessary to be separation between the roles of the CEO from Chairman (Fama \& Jensen, 1983).

Fosberg (2004) found that companies characterized by the separation of the CEO for the post of Chairman of the Board employs an optimal debt ratio in their financial structures, by using high leverage ratios, but that relationship was not statistically significant, While, Abor (2007) has provided an evidence of a positive relationship between CEO duality and Leverage. In contrary Ganiyu and Abiodun (2012) founds a negative relationship between CEO duality and financial leverage. 
Also CEO compensation is one of corporate governance indicators that have an impact on the trend of company toward adopting external or internal funding, several studies have indicated to the existence of a correlation between CEO compensation and financial structure of the company (Stulz, 2000, Brezeanu and Essawi, 2011). Abor et al. (2008) indicates that companies which promote a fixed bonuses to the CEO adopts low leverage in order to reduce risk, also (Wen et al. 2002) prove that there is an inverse relationship between compensation of CEO and financial leverage.

As we seen above all results of previous studies regarding the effect of (CGI) in financial leverage are inconclusive.

\subsection{Financial Leverage}

Financial leverage defined as the amount of debt which is obtained for needed financing in order to acquire the necessary property (Berman and Knight, p. 298). According to the mentioned definition, the firms can be defined based on the financing as firms with high and low degree of financial leverage.

Financial Leverage is one of the Leverage ratios which indicate the ability of firm to pay debts. In general, the leverage ratios indicate the amount of debts in the capital structure of company funding, and the best ratio to use is debt to equity (Berman and Knight, p. 299). When firm uses debt in its capital structure it has three important implications: First, through funding by the debt, the shareholders' ownership will not weaken, Second, creditors look to the equity it offers a margin of safety, Because if shareholders have given a percentage of total funding, the risks will create mainly by creditors, Third: if the firm earns higher returns on investments with debt financed, then it pay in interest, therefore, the return on equity will rise (Al- Haddad et al., 2011).

\section{Hypotheses of the study}

\subsection{The main hypothesis}

Corporate Governance Indicators (CGI): (Ownership Concentration, Board Size, CEO Duality, and CEO Compensations) don't leads Jordanian industrials firms to adopt high or low level of financial leverage.

\subsection{Sub-hypotheses:}

- High level of Ownership Concentration doesn't lead the firm to adopt high or low level of financial leverage.

- $\quad$ Large size of Board doesn't lead the firm to adopt high or low level of financial leverage.

- CEO Duality doesn't lead the firm to adopt high or low level of financial leverage.

- High level of CEO Compensation doesn't lead the firm to adopt high or low level of financial leverage.

\section{Research methodology}

\subsection{Data collection}

Data was collected through collecting and analyizing the annual financial reports of Jordanian industrial companies which listed in the ASE under the following conditions:

- The annual reports which were available for the company during the study period from 2003 to 2012. 
- Company must not be exposed to the merger during the study period.

- $\quad$ Data available for the (CGI) for every firm during the study period.

The above mentioned conditions, lead to the selection of a sample of (48) Company, where accounted for $50 \%$ of industrial companies listed on the ASE (Financial Securities Commission, 2012).

\subsection{Research Variables}

Many studies have confirmed that ownership concentration, the Board size, CEO Duality and CEO compensation are considered as indicators of corporate governance that have impact on the financing decisions in the company (Anderson et al., 2004, Fosberg, 2004, Hart and Moore, 1995). This study investigated the impact of a range of Corporate Governance indicators on financial leverage for a sample of Jordanian industrial companies, where independent variables are (Ownership Concentration, Board size, CEO Duality, CEO Compensation), While financial leverage is the dependent variable.

\subsubsection{Independent variables}

- Ownership Concentration: many studies confirmed that ownership concentration represents the major shareholders who own $5 \%$ or more of the shares of the firm, and this is consistent with the definition used in the Amman Stock Exchange, according to that it is calculated using the ownership of 5\% or above from the total ownership for each year of the study.

- Board Size: many studies confirmed that, the optimal number of the Board is located between 9-15 members (Adewuyi \& Olowookere, 2009). In the Jordan's Companies Act number (22) for the year 1997 and the amended law number (40) for the year 2002 in the article (132 / a) it mentioned: "Number of members of the Board of Directors of the company must be not less than three members and not more than thirteen members". Accordingly, the board size is calculated by dividing the number of members of the Board on (13) which represent $100 \%$, in order to get a percentage for each year of the study.

- CEO Duality: is included as a binary variable (= 1, if CEO Chairman, otherwise, 0$)$ for each year of the study.

- CEO Compensations: is measured by natural logarithm of total bounces, incentives and salaries for each year of the study.

\subsubsection{Dependent variable}

Financial Leverage: $\quad$ is measured as Total Debt/ Total Equity for each year of the study.

\subsection{Research Models}

In this section, regression analysis will be used to determine if all corporate governance indicators have effect on financial leverage and which of them have direct effect on the decision of the company to lead it to adopt low or high level of financial leverage, through a sample of (48) industrial companies selected randomly from ASE. This study contains four independent variables (Ownership Concentration, Board Size, CEO Duality and CEO Compensation) and the dependent variable Financial Leverage. The following general regression equation will be used:

$$
\mathrm{F}-\mathrm{L}=\beta_{0}+\beta_{1} \mathrm{O}-\mathrm{C}+\beta_{2} \mathrm{~B}-\mathrm{Z}+\beta 3 \mathrm{D}-\mathrm{L}+\beta_{4} \mathrm{Log} \mathrm{CEO}-\mathrm{Co}+\varepsilon \mathrm{i}
$$


Where: F-L: Financial Leverage, O-C: Ownership Concentration, B-Z: Board size, D-L: CEO Duality, Log CEO-Co: natural logarithm of CEO compensation, $\beta \mathrm{t}$ : the regression coefficients, \&i: random error in the regression equation. The following sub simple regression models will be used to test the effect of each independent variable on the dependent variable Financial Leverage:

$$
\begin{gathered}
\text { F-L }=\beta_{0}+\beta_{1} \mathrm{O}-\mathrm{C} \\
\mathrm{F}-\mathrm{L}=\beta_{0}+\beta_{1} \mathrm{~B}-\mathrm{Z} \\
\mathrm{F}-\mathrm{L}=\beta_{0}+\beta_{1} \mathrm{D}-\mathrm{L} \\
\mathrm{F}-\mathrm{L}=\beta_{0}+\beta_{1} \text { Log CEO-Co }
\end{gathered}
$$

To test these models and to obtain accurate results, the following tests have been conducted:

- Descriptive statistics to calculate the mean and standard deviation of each variable in the study.

- Pearson correlation matrix: this matrix is used to determine correlations between variables and to make sure that there is no problem of autocorrelation between the independent variables.

- Choosing between fixed and random effects: the generally accepted way of choosing between fixed and random effect is through running a Hausman test. Statistically, fixed effects are always a reasonable thing to do with panel data (they always give consistent results) but it may not be the most efficient model to run. Random effects will give you better P-values as they are a more efficient estimator, so you should run random effects if it is statistically justifiable to do so. The Hausman test checks a more efficient model against a less efficient but the consistent model is to make sure that the efficient model also gives consistent results.

- The following tests were used to check the significance of the models: T-test, F-test, Durbin_Waston test.

\section{Analysis}

\subsection{Descriptive Statistics}

Table (1) shows the descriptive statistics of the variables of the research. As seen from the table below, the mean of financial leverage (F-L) is $57.86 \%$ comparing with equity in industrial Jordanian firms, which means that firms adopt low level of leverage with standard deviation $71.05 \%$ between firms forming the sample. Also we can see that the mean of ownership concentration (O-C) in the sample is $49.29 \%$ with standard deviation $23.77 \%$, which support our previous discussion that stocks of industrial firms in Jordan held by numbers of investors representing financial institutions, insurance companies and government agencies (Block Shareholders). The mean of members of the board (B-Z) is $68.66 \%$ with standard deviation $15.03 \%$, which represent 9 members, and this figure is in line with Jordan's Companies Act and previous studies (Adewuyi \& Olowookere, 2009), we can also conclude from standard deviation that industrial firms are closely in the number of board members. Jordanian industrial firms pursue double position of Chairman and CEO in the same time (D-L), because $40.32 \%$ of observation during period research shows that Jordanian 
firms adopt CEO duality. The last CGI is compensation of CEO (Log CEO-Co) shows that CEO has a mean of compensation log 9.46 which represent (18750) Jordan Dinar.

Table 1. Descriptive Statistics

\begin{tabular}{|c|c|c|c|c|c|}
\hline Variables & F-L & O-C & B-Z & D-L & $\begin{array}{c}\text { Log } \\
\text { CEO -Co }\end{array}$ \\
\hline Mean & 0.5786 & 0.4929 & 0.6866 & 0.4032 & 9.46 \\
\hline Median & 0.3560 & 0.5411 & 0.6920 & 0.0000 & 9.66 \\
\hline Maximum & 5.13 & 0.9128 & 1.0000 & 1.0000 & 11.73 \\
\hline Minimum & 0.004 & 0.0100 & 0.3850 & 0.0000 & 7.14 \\
\hline St. Deviation & 0.7105 & 0.2377 & 0.1503 & 0.4913 & 1.18 \\
\hline Observations & 480 & 480 & 480 & 480 & 480 \\
\hline
\end{tabular}

\subsection{Correlation Coefficient}

This part will present the Pearson correlation matrix which indicates all variables included in the analysis as listed in the following table (2).

Table 2. Correlation Matrix of Variables

\begin{tabular}{|r|c|c|c|c|c|}
\hline \multicolumn{1}{|c|}{ Variables } & F-L & O -C & B-Z & D-L & $\begin{array}{c}\text { Log } \\
\text { CEO-Co }\end{array}$ \\
\hline F-L & 1.0000 & & & & \\
\hline O -C & $0.1136^{* *}-$ & 1.0000 & & & \\
\hline B-Z & $-0.1400^{* *}$ & $-0.1616^{* * *}$ & 1.0000 & & \\
\hline D-L & 0.0418 & $0.0931^{*}$ & -0.0736 & 1.0000 & \\
\hline $\begin{array}{r}\text { Log } \\
\text { CEO-Co }\end{array}$ & 0.0475 & $0.2087^{* * *}$ & $-0.3113^{* * *}$ & $0.1234^{* *}$ & 1.0000 \\
\hline
\end{tabular}

*,**,***: Significant at 10\%, 5\%, 1\% Respectively.

Results of Correlation between independent variables show that there is no high correlation, which means we don't have multicollinearity problem in the model. As seen above correlation between F-L and CGI (O-C, B-Z) is negative $(-11.36 \%,-14 \%)$ respectively and significant at $5 \%$, which means increasing of ownership concentration and Board size lead the firm to lower financial leverage. While correlation between F-L and CGI (D-L, Log CEO-Co) is positive $(4.18 \%, 4.75 \%)$ respectively and insignificant, which means that firms 
with CEO duality increased the level of financial leverage but this relation is very weak and insignificant, also the same result when firms pay high compensation for CEO's they increased the level of financial leverage but this relation is also very weak and insignificant.

\subsection{Testing Hypothesis}

In this part the researcher examine the effect of CGI on financial leverage of the industrial Jordanian firms, by using fixed effects model.

\subsubsection{Main Hypothesis}

Ho: Corporate Governance Indicators (Ownership Concentration, Board Size, CEO Duality, and CEO Compensation) don't lead Jordanian industrials firms to adopt high or low level of financial leverage.

Table (3) below show the results of multiple regression effect of all CGI on financial leverage model (1), the analysis result showed that coefficients indicates a significant negative correlation between (O-C, B-Z) and (F-L), while correlation between (D-L, Log CEO-Co) and (F-L) is positive and insignificant. The $\mathrm{R}^{2}$ test shows, a percentage of the explanation of all independent variables from the dependant variable (F-L), reached to $39.64 \%$. Also $F$ test indicates that F. statistic value is (07.81) and Probability F (0.000), which means that the model is fit. It should be noted that the optimum value for Durbin-Watson (DW) which refers to no serial correlation is (2); and since the estimation output reveals that the DW reaches a value of (1.78), this mean that we reject having a serial correlation. According to these results we conclude that corporate governance indicators as a whole leads the Jordanian industrial firms listed on the ASE to adopt low or high level of financial leverage.

Table 3. Multiple Regression of CGI on F-L Model (1)

\begin{tabular}{|r|c|c|c|}
\hline \multicolumn{1}{|l|}{ Dependant Variable: F-L } & \multicolumn{2}{l|}{ Fixed Effect } \\
\hline Variables & Coefficient & T.Statistic & P-Value \\
\hline O-C & -0.8473 & $-2.8948^{* *}$ & 0.0419 \\
\hline B-Z & -0.7589 & $-3.6918^{* * *}$ & 0.0010 \\
\hline D-L & 0.0197 & 0.2403 & 0.8103 \\
\hline Log CEO-Co & 0.0115 & 0.1073 & 0.9146 \\
\hline $\mathbf{R}^{2}$ & $39.64 \%$ & F. Statistic & 07.81 \\
\hline D.W & 1.78 & Prob (F) & 0.000 \\
\hline
\end{tabular}

**, ***: Significant at 5\%,1\% Respectively

\subsubsection{Sub- Hypothesis}

Table (4) below show the result of simple regression for models $(2,3,4,5)$, which represent the effect of each corporate governance indicator on financial leverage for Jordanian 
industrial firms listed on ASE. The analysis results showed the following:

Sub-Hypothesis 1 Model (2)

$\mathrm{H}_{01}$ : High level of Ownership Concentration in Jordanian industrial firms doesn't lead the firm to adopt high or low level of financial leverage.

From raw (2) results show that coefficient indicted a significant negative relationship between ownership concentration and financial leverage, with value of T. statistic (2.118) which is greater than tabulated $t$, and P-Value (0.0352) is less than $(0.05)$, which means that when ownership concentration increased the level of financial leverage decreased. The $\mathrm{R}^{2}$ test showed that ownership concentration (independent variable) explained $16.25 \%$ of variation in financial leverage (dependant variable). Depending on the above results, we reject the null hypothesis and accept the alternative hypothesis: High level of Ownership Concentration in Jordanian industrial firms lead the firm to adopt low level of financial leverage.

Sub-Hypothesis 2 Model (3)

$\mathbf{H}_{02}$ : Large size of Board in Jordanian industrial firms doesn't lead the firm to adopt high or low level of financial leverage.

From raw (3) results show that coefficient indicted a significant negative relationship between Board size and financial leverage, with value of T. statistic (-3.990) which is greater than tabulated $t$, and P-Value $(0.0001)$ is less than $(0.05)$, this means when Board size increased the level of financial leverage decreased. The $\mathrm{R}^{2}$ test showed that the Board size (independent variable) explained $20.37 \%$ of variation in financial leverage (dependant variable). Depending on the above results, we reject the null hypothesis and accept the alternative hypothesis: Large size of Board in Jordanian industrial firms lead the firm to adopt low level of financial leverage.

Sub-Hypothesis 3 Model (4)

$\mathbf{H}_{03}$ : CEO Duality in Jordanian industrial firms doesn't lead the firm to adopt high or low level of financial leverage.

From raw (4) results show that coefficient indicted insignificant positive relationship between CEO duality and financial leverage, with value of T. statistic $(0.731)$ which is smaller than tabulated $t$, and P- Value (0.4629) is greater than $(0.05)$. The $\mathrm{R}^{2}$ test showed that the CEO duality (independent variable) explained $3.7 \%$ of variation in financial leverage (dependant variable). Depending on the above results, we accept the null hypothesis: CEO Duality in Jordanian industrial firms doesn't lead the firm to adopt high or low level of financial leverage.

Sub-Hypothesis 4 Model (5)

$\mathrm{H}_{04}$ : High level of CEO Compensations in Jordanian industrial firms doesn't lead the firm to adopt high or low level of financial leverage. 
From raw (5) results show that coefficient indicted insignificant positive relationship between CEO compensations and financial leverage, with value of T. statistic (0.8612) which is smaller than tabulated $\mathrm{t}$, and P-Value $(0.3899)$ is greater than $(0.05)$. The $\mathrm{R}^{2}$ test shows, that the CEO compensations (independent variable) explained $4.2 \%$ of variation in financial leverage (dependant variable). Depending on the above results, we accept the null hypothesis: CEO Compensations in Jordanian industrial firms doesn't lead the firm to adopt high or low level of financial leverage.

Table 4. Simple Regression of each CGI on Fin-Lev for Models $(2,3,4,5)$

\begin{tabular}{|r|c|c|c|c|}
\hline Variables & \multicolumn{4}{|c|}{ Fixed Effect } \\
\cline { 2 - 5 } & Coefficient & T.Statistic & P-Value & $\mathbf{R}^{\mathbf{2}}$ \\
\hline $\begin{array}{r}\text { Model 2 } \\
\text { O-C }\end{array}$ & -1.2403 & $-2.118^{* *}$ & 0.0352 & $16.25 \%$ \\
\hline $\begin{array}{r}\text { Model 3 } \\
\text { B-Z }\end{array}$ & -0.7245 & $-3.990^{* * * *}$ & 0.0001 & $20.37 \%$ \\
\hline $\begin{array}{r}\text { Model 4 } \\
\text { D-L }\end{array}$ & 0.0605 & 0.731 & 0.4629 & $3.7 \%$ \\
\hline Model 5 Log CEO-C0 & 0.0789 & 0.8612 & 0.3899 & $4.2 \%$ \\
\hline
\end{tabular}

$* *$, ***: significant at 5\%,1\% respectively.

\section{Results Discussion}

According to the results of testing main hypothesis, corporate governance indicators in Jordanian industrial firms have significant effect on financial leverage, which means that CGI is playing an important role in determining the level of external debt. The all independent variables of (CGI) explained $39.64 \%$ of variation in financial leverage for these firms, ownership concentration and the Board size has the main significant effect in the model, while CEO Duality and CEO compensations have no effect in the model. The researcher concludes that CGI does matter in Jordanian industrial firms and leads the firm to adopt high/low level of financial leverage. Increasing shares are held by number of investors and increasing number of board members which have significant effect through leading the firm to adopt low level of debt in its capital structure, while firms adopting CEO duality and having high level of CEO compensation don't have any effect on financial leverage.

The results of simple regression of each CGI showed that ownership concentration is negatively correlated with financial leverage and has significant effect, when shares are held by number of investors increased, this lead the firm to lower the level of external debt, because shareholders believe that high level of debt in firm usually increases the probability of high risk, thus they prefer low level of debt. This result is consistent with results of correlation analysis and is in line with studies results of (Helen et al., 2002, Tong and Ning, 2004, Rehman et al., 2010). But this result is opposite to the results of others previous studies 
(Moeinaddin and Karimianrad, 2012, Ahmadpour et al., 2012). The researcher believes that Jordanian environment is different from other countries, in addition ASE is an emerging market which dominated by families and large shareholders (Banks, insurance companies, Government Agencies).

Results of simple regression showed that Board size is correlated negatively with financial leverage and has significant effect, when number of board members increases they prefer to pursue low level of external debt, because they try to protect the rights of shareholders through lowering the risks, which probably happening under the failure of firm to paid the cost of debt service, and Larger boards may emphasize owner-manager to employ more equity capital, in order to improve firm performance. This result is consistent with results of correlation analysis and also is in line with studies results of (Berger, 1997, Hasan and Butt, 2009) which argue that larger boards prefer low debt levels. But this result is opposite to other previous results (Abor, 2007, Rehman et al., 2010, Ahmadpour et al., 2012).

Results of simple regression showed that CEO Duality and CEO compensations are correlated positively with financial leverage, which means that firms adopt CEO duality and high level of compensation in Jordanian industrial firms adopt external debt in its capital structure, but these results are insignificant and don't have any effect on financial leverage, which means that if Jordanian industrial firms have one person for the position of CEO and Chairman in the same time or not this will not affect the decision of the firm to adopt high or low level of financial leverage and this result is also the same if the firm gives the CEO high or low level of compensation. These results are in line with studies results of (Wen et al., 2002, Abor, 2007, Abor et al., 2008, Hasan \& Butt, 2009, Ahmadpour et al., 2012).

\section{Conclusion}

This paper investigate the effect of four corporate governance indicators on financial leverage of Jordanian industrial Firms listed in ASE, the data was collected randomly for 48 firm. Financial leverage is used as a dependent variable, while corporate governance indicators (Ownership Concentration, Board Size, CEO Duality, CEO Compensation) are used as independents variables.

However, the summary of statistics shows that on average the industrial firms used $57.86 \%$ debt to equity to finance its assets and on average $49 \%$ of the shares are held by block shareholders. Also the average of the number of Board members is 9 and the average of CEO duality is $40.32 \%$ of observation during period research, while the average of compensation for CEO is (18750) Jordan Dinar.

Corporate governance indicators do matter in Jordanian industrial firms and have significant effect on financial leverage, which means that they lead the firm to adopt high/low level of external debt. Ownership Concentration and Board Size has significant negative effect on financial leverage, when they increased they lead the firm to adopt low level of external debt, while firms adopt double position of CEO/Chairman of the Board and high compensation for CEO follows high level of external debt, but these results are insignificant. The variable which has the main influence on financial leverage is the Board size then the Ownership 
concentration.

\section{Recommendations}

As noted, the corporate governance and its effect on various aspects of firms is one of the most important modern issues. Unfortunately, the background of internal research in Jordan is too low compared to the external background. According to research findings the below research recommendations are presented:

- The researcher calls the investors when taking investment decisions to take into consideration the Jordanian industrial companies which adopt low level of leverage in their capital structure which means that depending on internal funding will increase the cost of capital especially when the company issues new stocks and this will lower return on equity. On the other side adopting low level of external debt will protect the rights of shareholders through lowering the risks, which probably happen under the failure of firm to pay the cost of debt service.

- The researcher is calling the Jordanian industrial firms to be more clear in their annual reports regarding information about other corporate governance indicators like the number of independent members on the Board, number of meetings of the Board during the year, because there is a lack of information regarding these indicators.

- The researcher encourages other researchers to investigate the effect of other corporate governance indicators on financial leverage which has not been taken in this study, especially in industrial sector and banks sector.

\section{References}

Abor, J. (2007). Corporate Governance and financing decisions of Ghanaian listed firms, Corporate Governance: International Journal of Business in Society, 7(1), 83-92. http://dx.doi.org/10.1108/14720700710727131

Abor, J., Biekpe, \& Nicholas (2008). Does Corporate Governance affect the Capital Structure Decision of Ghanian SMES? University of Stennenbosch. Business School, South Africa.

Adewuyi, A. O., \& Olowookere, A. E. (2009). Impact of Governance Instruments on the Productivity of Nigerian Listed Firms. The Icfai University Journal of Corporate Governance, $\operatorname{VIII}(3), 51-74$.

Ahmadpour, A., Samimi, A., \& Golmohammadi, H. (2012). Corporate Governance and Capital Structure: Evidence from Tehran Stock Exchange. Middle -East Journal of Scientific Research, 11(4), 531-535.

Al - Haddad W., Alzurqan S., \& Al -Sufy F. (2011). The Effect of Corporate Governance on the Performance of Jordanian Industrial Companies: An empirical study on Amman Stock Exchange. International Journal of Humanities and Social Science, 1(4), 55-69.

Anderson, R., Mansi, S. A., \& Reeb, D. M. (2004). Board characteristics, accounting report integrity, and cost of debt. Journal of Accounting and Economics, 37, 315-342. 
http://dx.doi.org/10.1016/j.jacceco.2004.01.004

Awan, S., \& Khan, s. (2012). Effect on board composition on firm performance: A case of Pakistan listed companies. Interdisciplinary Journal of Contemporary Research in Business, 3(10), pp. 853-863. Available at: http://journal-archieves15.webs.com/853-863.pdf.

Berger, P.G., Ofek, E., \& Yermack, D.L. (1997). Managerial Entrenchment and Capital Structure Decisions. Journal of Finance, 52(4), 1411-1438. http://dx.doi.org/10.1111/j.1540-6261.1997.tb01115.x

Berman, K., \& Knight, J. (2006). Financial Intelligence, A manager's Guide to Knowing What the Numbers Really Mean. Business literacy Institute, Inc. First eBook Edition.

Brezeanu, P., \& Al Essawi, M. (2011). The Relationship between Financial Management and Corporate Governance: Analytical Approach at the Level of the Risk Management Strategies. Management \& Marketing Challenges for the Knowledge Society, 6(1), 151-162.

Chaghadari, M. (2011). Corporate Governance and Firm Performance. International Conference on Sociality and Economics Development IPEDR , 10, 484-489.

Core, J. E., Holthausen, R. W., \& Larcker, D. F. (1999). Corporate governance, chief executive officer compensation, and firm performance. Journal of Financial Economics, 51, 371-406. http://dx.doi.org/10.1016/S0304-405X(98)00058-0

Driffield, N., Mahambare, V., \& Pal, S. (2007). How does Ownership Structure Affect Capital Structure and Firm value? Economics of Transition, 15, 535-573. http://dx.doi.org/10.1111/j.1468-0351.2007.00291.x

Fama, E., \& Jensen, M. (1983). Separation of Ownership and Control, Journal of Law and Economics, 26(2), 301-325. http://dx.doi.org/10.1086/467037

Fosberg, R. H. (2004). Agency Problems and Debt Financing: Leadership Structure Effects ${ }^{\text {ee }}$ Corporate Governance. International Journal of Business in Society, 4(1), 31-38. http://dx.doi.org/10.1108/14720700410521943

Ganiyu, Y., \& Abiodun, B. (2012). The Impact of Corporate Governance on Capital Structure Decision of Nigerain Firms. Research Journal in Organizational Psychology \& Educational Studies, 1(2), 121-128.

Gillan S.L. (2006). Recent Developments in Corporate Governance: An Overview. Journal of Corporate Finance, 12, 381 - 402. http://dx.doi.org/10.1016/j.jcorpfin.2005.11.002

Hart, O., \& Moore, J. (1995) Debt and Seniority: an Analysis of the Role of Hard Claims in Constraining Management, American Economic Review, 85, 567-585.

Hasan A., \& Butt S. (2009). Impact of Ownership Structure and Corporate Governance on Capital Structure of Pakistani Listed Companies. International Journal of Business and Management, 4(2), 50-57. http://dx.doi.org/10.5539/ijbm.v4n2p50

Helen S., Kevin K., \& Darren, D. (2002). Capital Structure, Management Ownership and 


\section{Macrothink}

Journal of Management Research ISSN 1941-899X 2014, Vol. 6, No. 3

Large External Shareholders: A UK Analysis. International Journal of the Economics of Business, 9(3), 375-399. http://dx.doi.org/10.1080/1357151021000010382

Jordan's Companies Act number (22), 1997 and the amended law number (40), 2002.

Moeinaddin, M., \& Karimianrad, M. (2012). The Relationship between Corporate Governance and Finance Patterns of the Listed Companies, Interdisciplinary Journal of Contemporary Research in Business, 4(7), 489-500.

Rehman, M., Rehman, R., \& Raoof, A. (2010). Does corporate governance lead to a change in the capital structure? American Journal of Social and Management Sciences, 1(2), 191-195. http://dx.doi.org/10.5251/ajsms.2010.1.2.191.195

Shleifer, Andre, Vishny, \& Robert W., A (1997). Survey of Corporate Governance, Journal of Finance, 52(2), 737-783.

Stulz, R.M. (2000). Diminishing the Threats to Shareholder Wealth. Financial Times, Series Mastering Risk, 8-10.

Tong, S., \& Ning, Y. (2004). Does capital structure affect institutional investor choices? The Journal of Investing, 13(4), 53-66. http://dx.doi.org/10.3905/joi.2004.450757

Wen, Y., Rwegasira, K., \& Bilderbeek, J. (2002). Corporate Governance and Capital Structure Decisions of the Chinese Listed Firms. Corporate Governance: An International review, 10(2), 75-83.

Zubaidah Z.A., Nurmala M.K. \& Kamaruzaman J.( 2009). Board Structure and Corporate Performance in Malaysia. International Journal of Economic and Finance, 1(1), 150-164.

Annual Reports of Jordanian Industrial Firms. (2003-2012). http://www.jsc.gov.jo/

Jordanian Financial Securities Commission. (2012). http://www.jsc.gov.jo/

OECD Principles of Corporate Governance. (1999). Available at: http//www.oecd.org/dataoecd/32/18/31557724.pdf. 